\section{Temperature and Light Characterization during Winter Production Season in High Tunnels in the Southwestern United States}

\author{
Mark E. Uchanski ${ }^{1}$, Dawn M. VanLeeuwen ${ }^{2}$, Steven J. Guldan ${ }^{3,4}$, \\ Constance L. Falk ${ }^{5}$, Manoj Shukla ${ }^{4}$, and Juliette Enfield ${ }^{4}$
}

AdDitional INDEX wORDs. hoop house, $P A R$, photosynthetically active radiation, polytunnel, row cover, season extension

SUMMARY. Replicated temperature data from passively heated high tunnels are lacking, especially in the southwestern United States. Field studies were conducted over three seasons in two locations in New Mexico-a southern site in Las Cruces and a northern site in Alcalde - to characterize the crop environment in three hightunnel designs during the winter growing season (October-March). High tunnels were $16 \times 32 \mathrm{ft}$ and oriented with the long edge running east to west. Heavyweight woven plastic covered the single-layer (SL) high-tunnel design. Double-layer designs (DL) were covered with a lightweight woven plastic on the bottom, followed by a second layer of the heavyweight plastic inflated with a fan. A heat sink was created using 1655 -gal barrels painted black, filled with water, and aligned along the north side of the double layer for the DL + B design. Soil temperature ( 3 inches deep) and air temperature ( $1 \mathrm{ft}$ above the soil surface) were recorded inside the high tunnel, inside the high tunnel under a floating rowcover, and outside the high tunnel. In addition, photosynthetically active radiation $(P A R)$ was recorded inside and outside the high tunnels during or near the winter solstice each year of the study. Daily air and soil temperature minimums were highest in the DL $+B$ design and lowest in the SL design. Maximum air and soil temperatures did not significantly differ between high-tunnel designs, although the DL + B design measurements were consistently lower. During season 1, the SL design had significantly higher $P A R$ transmission than the other two designs. In the northern location, the difference became insignificant during seasons 2 and 3, likely due to dust accumulation and plastic aging. In the southern location, the SL design maintained higher $P A R$ transmission throughout the study, possibly due to plastic cleaning. Data collected in this study can help inform the decisions of high-tunnel growers and researchers in the region.

$\mathrm{H}$ igh tunnels are one way for growers to modify the crop growth environment (Giacomelli, 2009). A high tunnel is defined as a plastic-covered, passively heated, walk-in, semipermanent structure (Jimenez et al., 2005). High tunnels offer some crop protection from insect infestations, rain, snow, and cold weather (Giacomelli, 2009). Generally, no supplemental or artificial heat source is used to create suitable conditions for crop production (referred to as passive-solar heating). The simplest and least-expensive design is a small high tunnel (e.g., $16 \times$ $32 \mathrm{ft}$ ) that uses a single layer of translucent 6-mil polyethylene film, often treated with an ultraviolet light inhibitor, and that is constructed by the farmer on-site (Jimenez et al., 2005).

Most research in the United States has focused on crop production in high tunnels in the northeastern and mid-Atlantic states, including
Pennsylvania (Lamont et al., 2003; Orzolek et al., 2004), New Jersey (Both et al., 2007), and Connecticut (Gent, 1992). Gent (1992) found that low irradiance limited production during the fall in high tunnels in the northeastern United States. Interest and research has expanded to other areas of the United States, including the Northwest (Borrelli et al., 2013) and Upper Midwest (Flavin Hodge et al., 2019). Research and literature on the use of these structures for winter production in mediumto high-elevation (1250 to $1700 \mathrm{~m}$ ), semiarid areas of the Southwest (New Mexico, Arizona, and Colorado) is limited (Carey et al., 2009), although recent studies in New Mexico are encouraging (Hecher et al., 2014; Heyduck et al., 2019). Although northern latitude states experience long winters with short days and frequent overcast conditions, the southwestern United States has predominately sunny days. Even during winter, New Mexico receives $70 \%$ to $75 \%$ of the possible sunshine (New Mexico Climate Center, 2019). Due to geographic location and limited cloud cover, the Southwest receives more sunlight than any other region of the United States.

The use of high tunnels could allow New Mexico growers to extend greens production into the winter months and fill the winter production gap. Partially due to elevation, New Mexico winters are relatively cold and characterized by large annual and diurnal temperature ranges, low humidity, and low precipitation. Therefore, high tunnels could be used as a way of modifying the crop production environment in New Mexico, but detailed temperature information is limited.

The air temperature inside a typical single-layer plastic high tunnel will drop to the same temperature as the outside air at night if there is no heat curtain (a curtain that is used to trap heat inside the high tunnel) or other source of supplemental heat (Both et al., 2007). Additional hightunnel structural inputs could increase the capacity of the high tunnel to retain heat as the temperature drops during the night, but they will increase the cost of the structure. For example, a double layer of plastic film can insulate the sidewalls and roof of the high tunnel, and a thermal mass (such as water or rocks) can capture, retain, and release heat into the high tunnel at night. In a high-tunnel study comparing different tunnel designs and spring tomato (Solanum

\begin{tabular}{llll}
\hline $\begin{array}{l}\text { Units } \\
\text { To convert U.S. to SI, } \\
\text { multiply by }\end{array}$ & U.S. unit & SI unit & $\begin{array}{l}\text { To convert SI to U.S., } \\
\text { multiply by }\end{array}$ \\
\hline 0.3048 & $\mathrm{ft}$ & $\mathrm{m}$ & 3.2808 \\
0.0283 & $\mathrm{ft}^{3}$ & $\mathrm{~m}^{3}$ & 35.3147 \\
3.7854 & gal & $\mathrm{L}$ & 0.2642 \\
2.54 & inch(es) & $\mathrm{cm}$ & 0.3937 \\
25.4 & inch $(\mathrm{es})$ & $\mathrm{mm}$ & 0.0394 \\
$\left({ }^{\circ} \mathrm{F}-32\right) \div 1.8$ & ${ }^{\circ} \mathrm{F}$ & ${ }^{\circ} \mathrm{C}$ & $\left({ }^{\circ} \mathrm{C} \times 1.8\right)+32$
\end{tabular}


lycopersicum) plant sowing dates in Tokat, Turkey, it was found that a double-layer high tunnel had a higher tomato yield than a singlelayer high tunnel, likely due to increased temperatures (Saglam and Yazgan, 2000).

Rowcovers typically increase temperatures 2 to $3{ }^{\circ} \mathrm{C}$ (Wells and Loy, 1993), and can also moderate temperature fluctuations. Air under rowcovers warms faster on cool mornings than ambient air in a high tunnel, and the heat is retained under rowcovers for longer in the afternoon (Wells and Loy, 1993).

Given the space limitations in high tunnels, extensive replicated testing of different species and varieties of horticultural crops is difficult. Environmental data can provide important baseline information used to describe the potential of high tunnels

Received for publication 12 Aug. 2019. Accepted for publication 7 Feb. 2020

Published online 5 March 2020.

${ }^{1}$ Department of Horticulture and Landscape Architecture, Colorado State University, Fort Collins, CO 80523

${ }^{2}$ Department of Economics, Applied Statistics, and International Business/Agricultural Biometric Service, New Mexico State University, Las Cruces, NM 88003

${ }^{3}$ Sustainable Agriculture Science Center at Alcalde, New Mexico State University, Alcalde, NM 87511

${ }^{4}$ Department of Plant and Environmental Sciences, New Mexico State University, Las Cruces, NM 88003

${ }^{5}$ Department of Agricultural Economics and Agricultural Business, New Mexico State University, Las Cruces, NM 88003

Funding for this research was provided by the Western Sustainable Agriculture Research and Education program (project SW09-041), the National Institute of Food and Agriculture, and the U.S. Department of Agriculture. Additional salaries and research support were provided by state and federal funds appropriated to the New Mexico State University Agricultural Experiment Station. We acknowledge the technical assistance of Mike Petersen, Victoria Frietze, Luz Hernandez, David Archuleta, David Salazar, Val Archuleta, and other Alcalde staff who assisted. In particular, we acknowledge Del Jimenez for his expertise and assistance in high-tunnel design and construction. We thank Ana Henke for production of the final figures and Frank Sholedice and Robert Heyduck for reviewing the manuscript.

M.E.U. is an Associate Professor.

D.M.V. is a Professor

S.J.G. is a Superintendent and Professor.

C.L.F. is an M. Eugene Sundt Honors Professor Emeritus

M.S. is a Professor.

J.E. is a Graduate Research Assistant.

S.J.G. is the corresponding author. E-mail: sguldan@ nmsu.edu.

This is an open access article distributed under the CC BY-NC-ND license (https://creativecommons.org/ licenses/by-nc-nd/4.0/).

https://doi.org/10.21273/HORTTECH04486-19 to support various crops grown during the winter. In this study, three passive-solar high-tunnel designs of different expense and expected heatretention capacities were evaluated across three winter seasons (200912) in southern New Mexico near Las Cruces [U.S. Department of Agriculture (USDA) plant hardiness zone 8a (USDA, 2019a)] and northcentral New Mexico at Alcalde [USDA plant hardiness zone 6a (USDA, 2019a)] for their capacity to provide a growing environment to produce a winter (OctoberMarch) crop: 1) a high tunnel with a single layer of woven polyethylene covering (SL), 2) a high tunnel with a double layer of woven polyethylene covering (DL), and 3 ) a high tunnel with a double layer of woven polyethylene covering plus a thermal mass of water barrels $(\mathrm{DL}+\mathrm{B})$.

\section{Materials and methods}

EXPERIMENT LOCATIONS. This study was carried out at two New Mexico State University agricultural research stations: Leyendecker Plant Science Research Center near Las Cruces, NM (Doña Ana County), and the Sustainable Agriculture Science Center in Alcalde, NM (Rio Arriba County). The Leyendecker Center is located at an elevation of $1174 \mathrm{~m}$ (lat. $32.20^{\circ} \mathrm{N}$, long. $\left.106.74^{\circ} \mathrm{W}\right)$. Las Cruces receives annual precipitation of 9.3 inches [Western Regional Climate Center (WRCC), 2013]. Based on 2009-12 data [National Oceanic and Atmospheric Administration (NOAA), 2012a], the average first fall freeze $\left(32{ }^{\circ} \mathrm{F}\right)$ date in Las Cruces was 6 Nov. and the average last spring freeze date was 15 Mar. The average maximum temperature in January was $58^{\circ} \mathrm{F}$ and the average minimum temperature in January was $28{ }^{\circ} \mathrm{F}$ (WRCC, 2013). The study was conducted on Belen clay loam soil [clayey over loamy, smectitic, calcareous, thermic, Vertic Torrifluvents (USDA, 2019b)] with $1.2 \%$ organic matter as tested in Fall 2009.

Alcalde is located at an elevation of $1734 \mathrm{~m}$ (lat. $36.09^{\circ} \mathrm{N}$, long. $106.06^{\circ} \mathrm{W}$ ), and receives annual precipitation of 10.0 inches (WRCC, 2016). Based on 2009-12 data (NOAA, 2012b), the average first fall freeze $\left(32{ }^{\circ} \mathrm{F}\right)$ date at Alcalde was 8 Oct. and the average last spring freeze date was 15 May. The average maximum temperature in January was $46^{\circ} \mathrm{F}$ and the average minimum temperature in January was $15^{\circ} \mathrm{F}$ (WRCC, 2016). The Alcalde study was conducted on Fruitland sandy loam soil [coarse-loamy, mixed, calcareous, mesic Typic Torriorthents (USDA, 2019b)] with $0.7 \%$ organic matter as tested in Fall 2009. The study was carried out at both locations from Oct. to Mar. 2009-10 (season 1), 2010-11 (season 2), and 2011-12 (season 3).

EXPERIMENTAL DESign. At each research station, the three high-tunnel designs were replicated twice. In Las Cruces, the six tunnels were arranged in a randomized complete block design due to possible soil type differences on the construction site. In Alcalde, the six high tunnels were arranged in a completely randomized design (CRD).

High-TUNNEL CONSTRUCTION. The construction of the high tunnels was based on a design by Jimenez et al. (2005) for New Mexico winter vegetable production, and further modified to include a larger straightframe base, light-transmitting end walls, and a woven plastic covering. The dimensions of the high tunnels were $32 \mathrm{ft}$ long $\times 16 \mathrm{ft}$ wide and $8 \mathrm{ft}$ tall (Fig. 1). Tunnels were oriented with the long side running east to west. This orientation aimed to maximize solar radiation transmission throughout the day during the winter months (Soriano et al., 2009). The frame of the high tunnel was built from $1.5 \times 3.5$-inch $(2 \times 4)$ and $3.5 \times$ 3.5 -inch $(4 \times 4)$ non-pressure-treated lumber and bent 2-inch-diameter polyvinylchloride (PVC) pipes.

Heavyweight $(\approx 0.20 \mathrm{~mm})$ woven plastic with ultraviolet and infrared light-inhibitor treatments (Solarig 172; PIC Plast, Afula, Israel) was used to cover the SL high tunnels. The DL and DL+B high tunnels were first covered with a lightweight $(\approx 0.16 \mathrm{~mm})$ woven plastic with ultraviolet and infrared light-inhibitor treatments (Solarig 140; PIC Plast), then covered with a second layer of the heavyweight woven plastic. The space between the two layers of plastic was inflated with inside air with a squirrel cage fan (Inflation System Replacement Blower $148 \mathrm{ft}^{3} / \mathrm{min}$; FarmTek, Dyersville, IA). The interior end walls in tunnel designs DL and $\mathrm{DL}+\mathrm{B}$ were covered with a second 


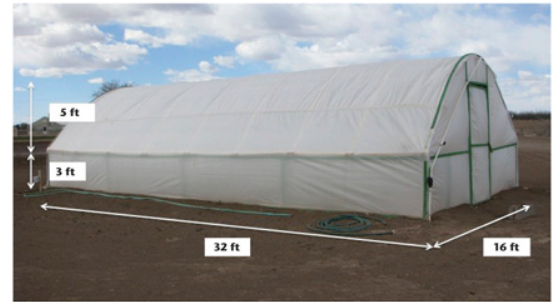

Fig. 1. Dimensions of double-layer (DL) straight-framed high tunnel; 1 $\mathrm{ft}=0.3048 \mathrm{~m}$.

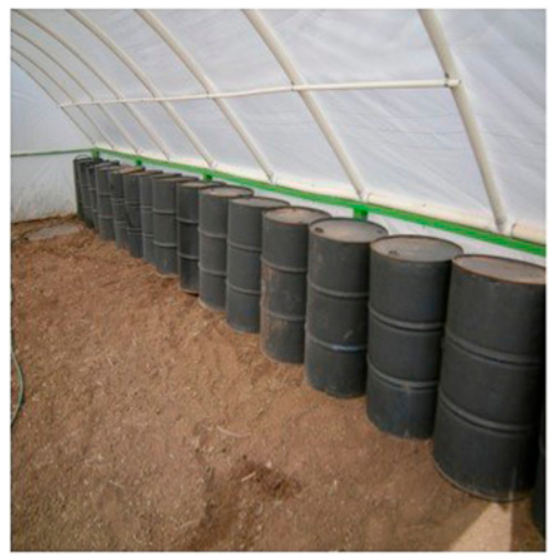

Fig. 2. Thermal mass of water barrels [16 barrels, each 55 gal (208.2 L)] aligned on the north side of a doublelayer plus barrels $(\mathrm{DL}+\mathrm{B})$ hightunnel design.

layer of the heavyweight woven plastic. Both end walls of all high-tunnel designs each had a single $4.0 \times 6.7-\mathrm{ft}$ access door. For each DL+B high tunnel, sixteen 55-gal metal drum barrels were painted with nonreflective black spray paint and filled with water (Fig. 2). These barrels were aligned along the inside of the north side of the $\mathrm{DL}+\mathrm{B}$ high tunnel to minimize shading of the crop. The six high tunnels at both sites were spaced a minimum of $35 \mathrm{ft}$ apart to prevent shading of the nearby high tunnels in the low winter sun. Hightunnel doors were kept closed during the winter growing season and were not opened for ventilation of the houses. Designed primarily for winter production, the high tunnels were built with fixed sides that did not allow ventilation. Lettuce (Lactuca sativa) and spinach (Spinacia oleracea) were grown in these high tunnels for a concurrent study. Crops were direct seeded in November and December in season $\mathrm{l}$ and October and
November in seasons 2 and 3 (Hecher et al., 2014). Plants were harvested, and re-growth harvested multiple times ("cut and come again"), when plants were generally 8 to $12 \mathrm{~cm}$ tall.

During season 1 in Las Cruces, the $\mathrm{SL}, \mathrm{DL}$, and $\mathrm{DL}+\mathrm{B}$ high-tunnel designs were not yet completed. The SL was covered with the heavyweight plastic, and the DL and DL+B designs were covered with only their first layer of plastic, the lightweight material. To take advantage of this opportunity, the effect of plastic thickness on temperatures was evaluated. During season 2 in Las Cruces, construction of all high-tunnel designs was completed and an analysis on the three different designs (SL, DL, and DL+B) was conducted.

ENVIRONMENTAL DATA COLLECTION. Two data loggers (Hobo Ul2-008 4channel external data logger; Onset Computer Corp., Bourne, MA) were mounted inside each high tunnel. Loggers were programmed to record temperatures once every $30 \mathrm{~min}$ from October to March. One soil and one air temperature sensor (air/water/ soil temperature sensor 6 - $\mathrm{ft}$ cable TMC6-HD; Onset Computer Corp.) were placed at each of two locations in each high tunnel: one location was under a floating (nonsupported) rowcover (Agribon AG-19; J\&M Industries, Ponchatoula, LA) and the other location was not covered (data not presented). One soil and one air temperature sensor were also placed outside each high tunnel for a total of six sensors deployed per high tunnel (Fig. 3). Soil temperature probes were buried horizontally 3 inches below the soil surface, and air temperature sensors were positioned vertically $\mathrm{l} \mathrm{ft}$ above the soil in solar radiation shields that were mounted to wooden or metal stakes. At Alcalde, each shield was constructed from five 6.4-inch-diameter melamine plates (Thunder Group, Inc., City of Industry, CA) separated with 1-inch-long, 0.75-inch PVC conduit spacers; 1 -inch holes were drilled in the center of the second and third plate from the bottom where the sensor was positioned, the bottom plate had a hole drilled slightly wider than the sensor to allow the sensor to pass through, and plates were connected with all-thread bolts. At Las Cruces, a combination of these shields and manufactured solar shields (RS3 Solar Radiation Shields; Onset Computer Corp.) were used.

Floating rowcovers were left on the plots throughout the study except for weeding, other plot maintenance, and while harvesting. Data were downloaded from the loggers at the end of the study season using HOBOware Pro software (version 2.7.3.1, 2002-2009; Onset Computer Corp.). When temperature data were visualized, upper $\left(22^{\circ} \mathrm{C}\right)$ and lower $\left(8^{\circ} \mathrm{C}\right)$ thresholds were added as horizontal lines for reference for a cool-season crop (Swiader and Ware, 2002).

During the month of Jan. 2012 (season 3) in Las Cruces, temperature was recorded in one of the center water barrels in one DL+B high tunnel using a separate data logger with a temperature air/soil/water probe attached. The sensor was inserted through the fill hole and suspended approximately a foot below the fill hole in the water of the barrel. Temperature data were used to summarize the daily low air temperatures (inside the high tunnel, but not under the rowcover) and the water temperature inside the barrel for the month of January.

$P A R$ was measured each season within 1 month of the winter solstice, 21 Dec., at noon. Measurements were taken at six locations associated with each high tunnel: outside the high tunnel, inside the high tunnel in the center walkway, inside the high tunnel on the north bed, inside the high tunnel on the south bed, inside the high tunnel on the north bed under the rowcover, and inside the high tunnel on the south bed under the rowcover. At Las Cruces, PAR was measured with a line sensor (LP80 Accupar PAR/LAI ceptometer; Decagon Devices, Pullman, WA), and at Alcalde, $P A R$ was measured with a quantum sensor (LightScout Quantum Meter; Spectrum Technologies, Plainfield, IL). Both devices were leveled before taking readings and recorded $P A R$ in micromoles per square meter per second. Temperature and $P A R$ sensors were factory calibrated.

Statistical analysis. Monthly average maximum and minimum soil and air temperature variables were analyzed separately by location (Alcalde and Las Cruces) and season ( 1 , 2 , and 3 ). The analyses included months from November through 


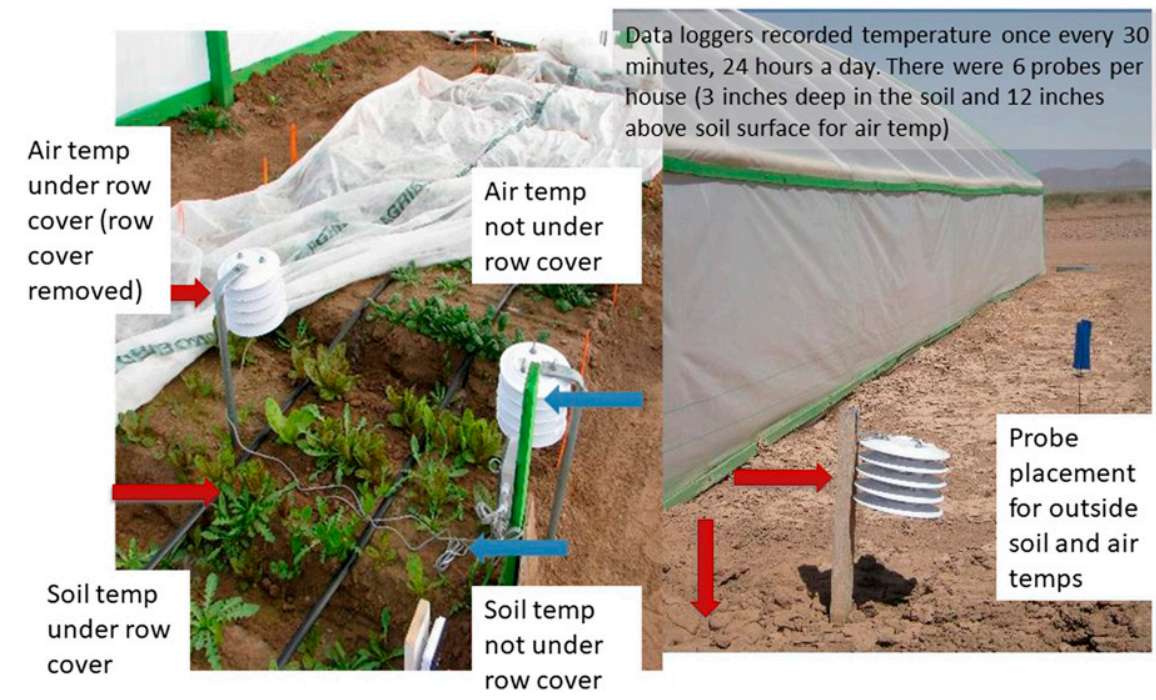

Fig. 3. Locations of air and soil temperature sensor probes inside and outside of high tunnels; 1 inch $=2.54 \mathrm{~cm}$.

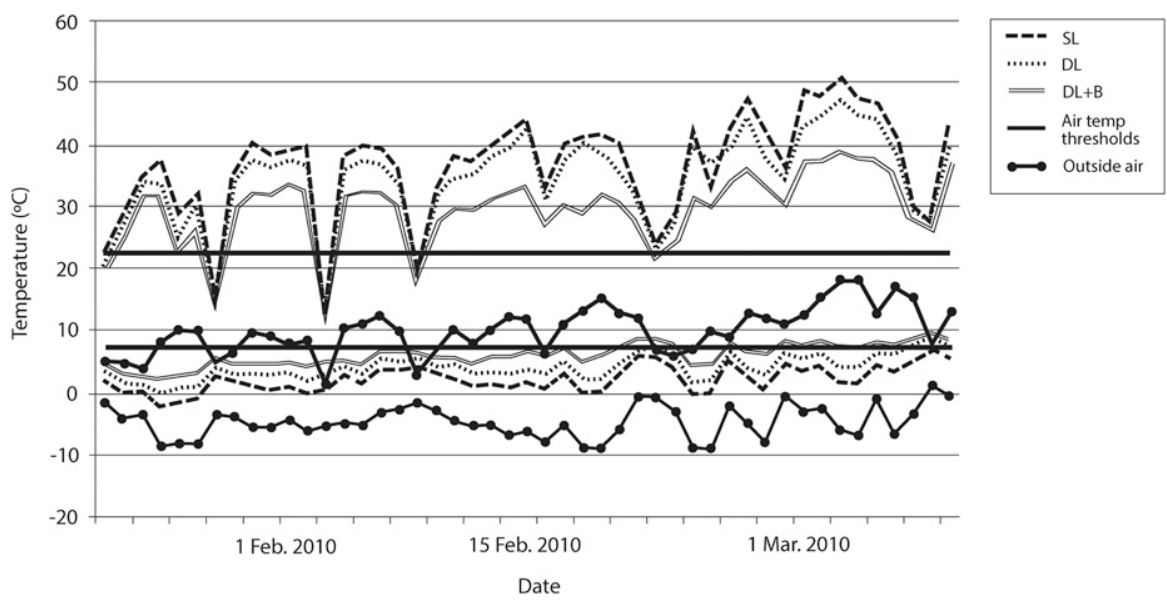

Fig. 4. Daily maximum and minimum air temperatures from under the rowcover inside three designs of high tunnel in Alcalde, NM, during season 1 (22 Jan. to 9 Mar. 2010). $S L=$ single-layer polyethylene, $\mathrm{DL}=$ double-layer polyethylene, $\mathrm{DL}+\mathrm{B}=$ double-layer polyethylene plus water barrels. Air temperature thresholds for cool-season leafy greens are referenced from Swiader and Ware (2002); $\left(1.8 \times{ }^{\circ} \mathrm{C}\right)+32={ }^{\circ} \mathrm{F}$.

February (months that had data for at least $20 \mathrm{~d}$ ). The effects of hightunnel design (SL, DL, and DL+B) on temperature were tested using a mixed model with fixed effects for high-tunnel design, month, and design $\times$ month. For data from Alcalde, a random effect for the high-tunnel experimental unit was included to account for repeated measures from within the same high tunnel. For data from Las Cruces, random effects for block, and block $\times$ month were added to the mixed model to account for blocking. In season l, only 1 month (February) had sufficient data to be included in the analysis, so that month and all effects including month were dropped from the mixed models. When the hightunnel design $\times$ month interaction was significant, the interaction effect was sliced by month with pairwise comparisons among high-tunnel designs only for those months in which the corresponding slice was significant. If the high-tunnel design main effect was significant but design $x$ month interaction was not, then overall high-tunnel design least squares means or differences and SE are reported.
$P A R$ was analyzed combining seasons 1, 2, and 3 for the Alcalde analysis and combining seasons 2 and 3 for the Las Cruces analysis. A mixed model was used with fixed effects for season, high-tunnel design, sensor location, and all interactions. For the CRD with repeated measures design at Alcalde, random effects for the high-tunnel experimental unit, and the high-tunnel experimental unit $x$ season interaction were included. Additional random effects for block and season $\times$ block were included in the analysis for Las Cruces. For the highest-order significant effect containing either high-tunnel design or sensor location, least squares means and means separation corresponding to simple effects of high-tunnel design or sensor location were reported. The PDMIX800 macro program was used to compare least squares means differences (Saxton, 1998). Mixed models were fit using Proc Mixed in SAS (version 9.3; SAS Institute, Cary, NC); significance was defined for $P \leq$ 0.05 . For temperatures and $P A R$, means are presented \pm SE. Hereafter in the text, model-based estimated means are referred to as estimates.

\section{Results}

Air temperature: Alcalde. During season 1 at Alcalde, only 1 month (February) had more than 20 $\mathrm{d}$ recorded. The monthly average maximum air temperature was not significantly different between designs in Feb. $2010(P=0.074)$, although Fig. 4 indicates that on warmer, sunny days $\mathrm{DL}+\mathrm{B}$ was 5 to $10{ }^{\circ} \mathrm{C}$ cooler than DL. For monthly average maximum temperatures, there was a significant design main effect $(P=0.021)$ for season 2 (Fig. $5)$, with the $\mathrm{DL}$ design having an estimated $2.5 \pm 0.4{ }^{\circ} \mathrm{C}$ higher mean than the $\mathrm{DL}+\mathrm{B}$ design. For season 3 (Fig. 6), there was a significant design $\times$ month interaction $(P=$ $0.017)$. Post hoc tests showed that in Jan. 2012, the $\mathrm{DL}+\mathrm{B}$ maximum temperature was $3.7 \pm 0.9{ }^{\circ} \mathrm{C}$ lower than the SL maximum temperatures. In Feb. 2012, the DL+B maximum temperature $\left(34.6 \pm 0.7{ }^{\circ} \mathrm{C}\right)$ was lower than either the SL $(38.0 \pm$ $\left.0.7^{\circ} \mathrm{C}\right)$ or the DL $\left(38.1 \pm 0.7^{\circ} \mathrm{C}\right)$.

For monthly average minimum temperatures, season 1 showed a significant difference among high-tunnel designs $[P=0.014$ (Fig. 4) $]$. The 


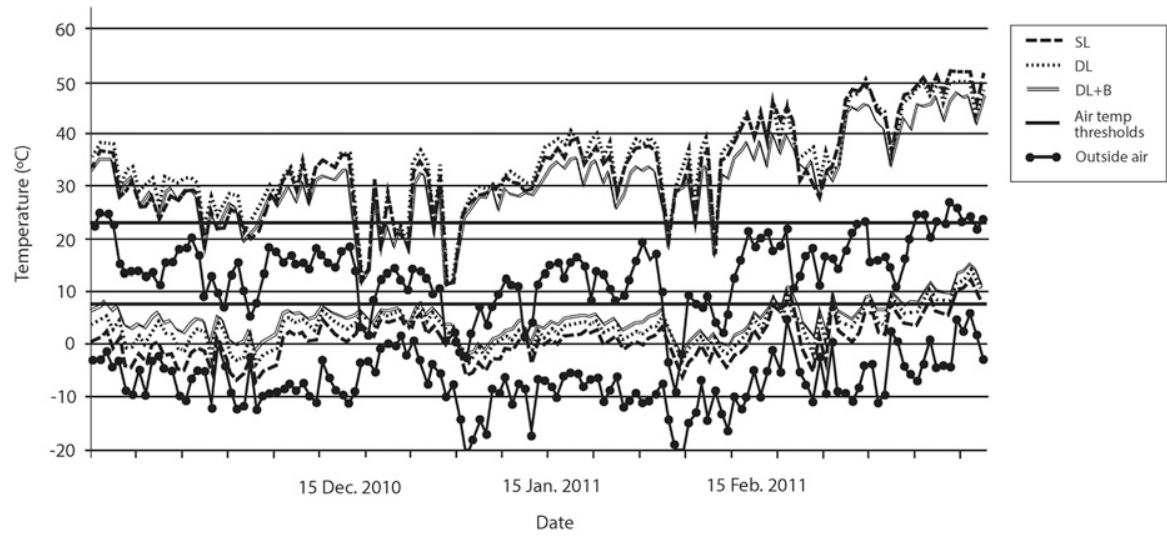

Fig. 5. Daily maximum and minimum air temperatures from under the rowcover inside three designs of high tunnels in Alcalde, NM, during season 2 ( 5 Nov. 2010 to 21 Mar. 2011). SL = single-layer polyethylene, $\mathrm{DL}=$ double-layer polyethylene, $\mathrm{DL}+\mathrm{B}=$ double-layer polyethylene plus water barrels. Air temperature thresholds for cool-season leafy greens are referenced from Swiader and Ware $(2002) ;(1.8 \times$ $\left.{ }^{\circ} \mathrm{C}\right)+32={ }^{\circ} \mathrm{F}$.

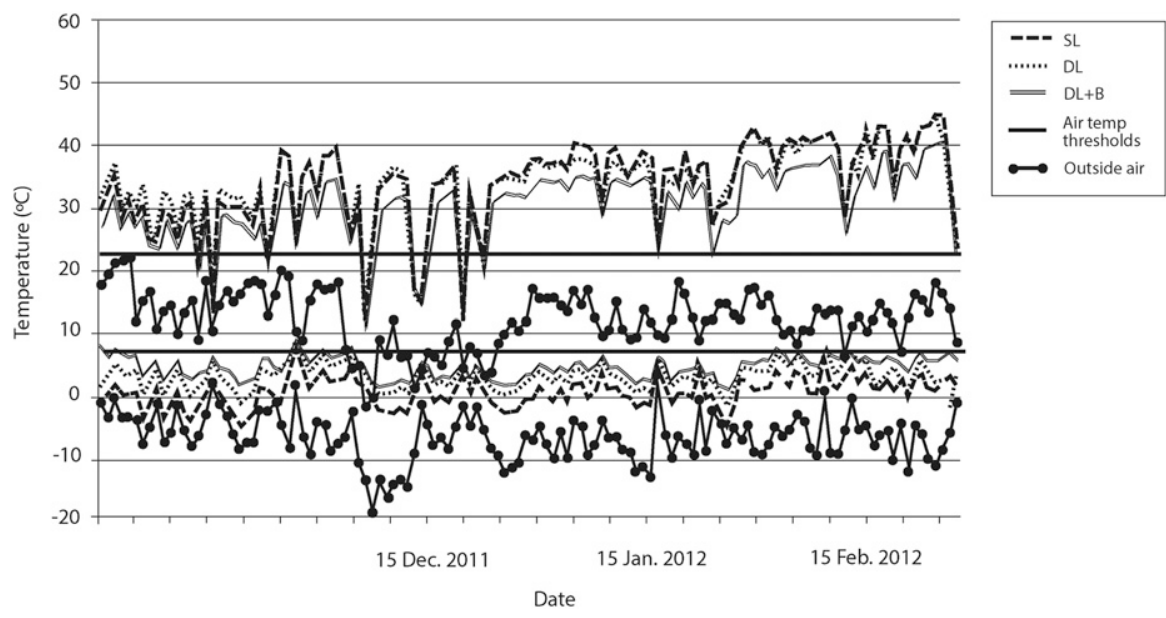

Fig. 6. Daily maximum and minimum air temperatures from under the rowcover inside three designs of high tunnels in Alcalde, NM, during season 3 (28 Oct. 2011 to 28 Feb. 2012). $\mathrm{SL}=$ single-layer polyethylene, $\mathrm{DL}=$ double-layer polyethylene, $\mathrm{DL}+\mathrm{B}=$ double-layer polyethylene plus water barrels. Air temperature thresholds for cool-season leafy greens are referenced from Swiader and Ware $(2002) ;\left(1.8 \times{ }^{\circ} \mathrm{C}\right)+32={ }^{\circ} \mathrm{F}$.

SL design had the lowest average February minimum $\left(2.3 \pm 0.4{ }^{\circ} \mathrm{C}\right)$, followed by the DL $\left(4.2 \pm 0.4^{\circ} \mathrm{C}\right)$ and then the $\mathrm{DL}+\mathrm{B}\left(6.3 \pm 0.4^{\circ} \mathrm{C}\right)$. There was a significant design $\times$ month interaction for both season $2[P<0.001$ (Fig. 5) $]$ and season $3[P=0.013$ (Fig. 6)]. For every month during both seasons, the $\mathrm{DL}+\mathrm{B}$ design had the highest minimum temperature and the SL design had the lowest minimum temperature. For season 2 , estimates of the difference between $\mathrm{DL}+\mathrm{B}$ and $\mathrm{DL}$ ranged from a high of $2.7 \pm 0.2^{\circ} \mathrm{C}$ during November to a low of $1.4 \pm 0.2{ }^{\circ} \mathrm{C}$ during December, whereas estimates of the difference between DL+B and SL ranged plastic thickness were compared. When February average maximum and average minimum temperatures were compared between high-tunnel designs with different thicknesses of plastic, no statistical differences were detected.

For monthly average maximum temperatures, no statistically significant differences were detected among high-tunnel designs in either season 2 $[P=0.127$ (Fig. 7 ) $]$ or season $3[P=$ 0.155 (Fig. 8)], although monthly averages for $\mathrm{DL}+\mathrm{B}$ were consistently the lowest. The monthly average minimum temperatures were significantly different among high-tunnel designs in season $2[P=0.021$ (Fig. 7 ) $]$ and season $3[P=0.003$ (Fig. 8)]. During both these seasons, the SL design had the lowest minimum temperature $\left(4.2 \pm 0.5{ }^{\circ} \mathrm{C}\right.$ for season 2 and $5.4 \pm$ $0.2^{\circ} \mathrm{C}$ for season 3 ), followed by the $\mathrm{DL}\left(6.3 \pm 0.5\right.$ and $\left.6.9 \pm 0.2^{\circ} \mathrm{C}\right)$ and then the DL+B $(8.2 \pm 0.5$ and $8.7 \pm$ $0.2{ }^{\circ} \mathrm{C}$ ) designs.

BARREL WATER TEMPERATURE: Las Cruces. During season 3 in Las Cruces, the temperature was recorded in a single water barrel in one $\mathrm{DL}+\mathrm{B}$ high tunnel. During Jan. 2012, the monthly average minimum air temperatures were 2.2 and $-0.6{ }^{\circ} \mathrm{C}$ in the $\mathrm{DL}+\mathrm{B}$ and DL, respectively, compared with a minimum water temperature of $17.5{ }^{\circ} \mathrm{C}$ in the barrels. This resulted in a 15.3 and $18.1^{\circ} \mathrm{C}$ difference between the barrel water temperature and air temperature inside the $\mathrm{DL}+\mathrm{B}$ and DL high-tunnel designs, respectively.

SoIl temperature. At Alcalde, monthly average maximum soil temperatures were not significantly different between high-tunnel designs for any of the three seasons (Figs. 911). Monthly average minimum soil temperature for SL $\left(7.8 \pm 0.2^{\circ} \mathrm{C}\right)$ was lower than the other high-tunnel designs during February of season 1 [ $P=$ 0.03 (Fig. 9); DL and DL+B minimum soil temperatures estimated as $9.0 \pm 0.2$ and $9.5 \pm 0.2^{\circ} \mathrm{C}$, respectively]. Season 2 (Fig. 10) showed a significant design $\times$ month interaction $(P=0.006)$. Although only the November slice was significant with both DL $\left(9.8 \pm 0.4{ }^{\circ} \mathrm{C}\right)$ and $\mathrm{DL}+\mathrm{B}$ $\left(10.9 \pm 0.4{ }^{\circ} \mathrm{C}\right)$ having higher estimated minimum soil temperature than SL $\left(7.8 \pm 0.2^{\circ} \mathrm{C}\right)$, numerically, within each month, the $\mathrm{DL}+\mathrm{B}$ estimate was highest, followed by the DL 


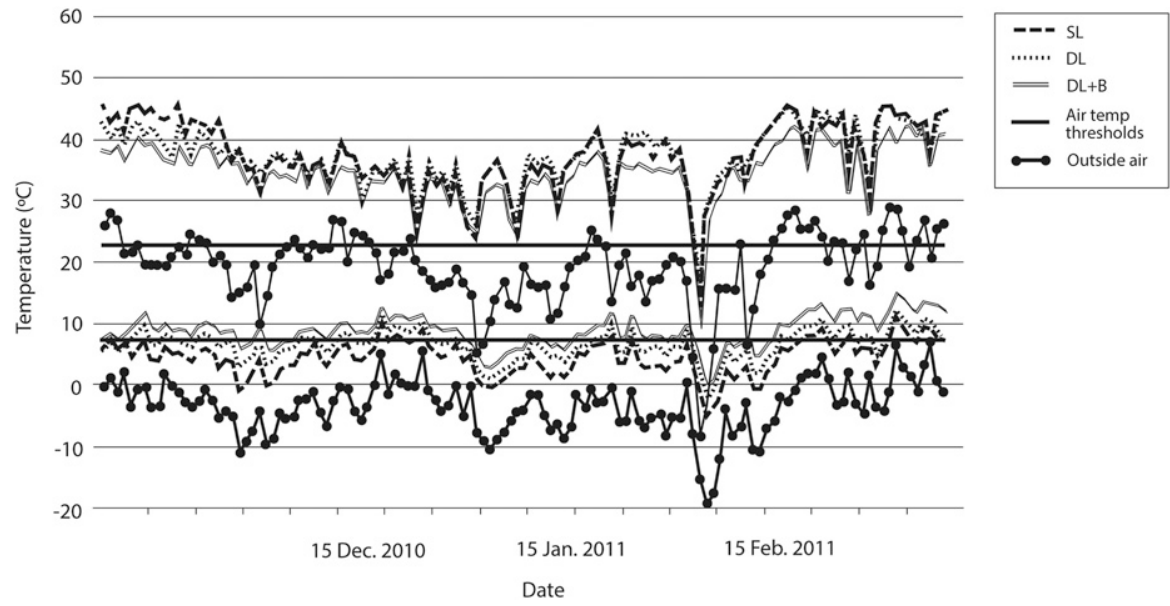

Fig. 7. Daily maximum and minimum air temperatures from under the rowcover inside three designs of high tunnels in Las Cruces, NM, during season 2 (6 Nov. 2010 to 9 Mar. 2011). SL = single-layer polyethylene, $\mathrm{DL}=$ double-layer polyethylene, $\mathrm{DL}+\mathrm{B}=$ double-layer polyethylene plus water barrels. Air temperature thresholds for cool-season leafy greens are referenced from Swiader and Ware (2002); $\left(1.8 \times{ }^{\circ} \mathrm{C}\right)+32={ }^{\circ} \mathrm{F}$.

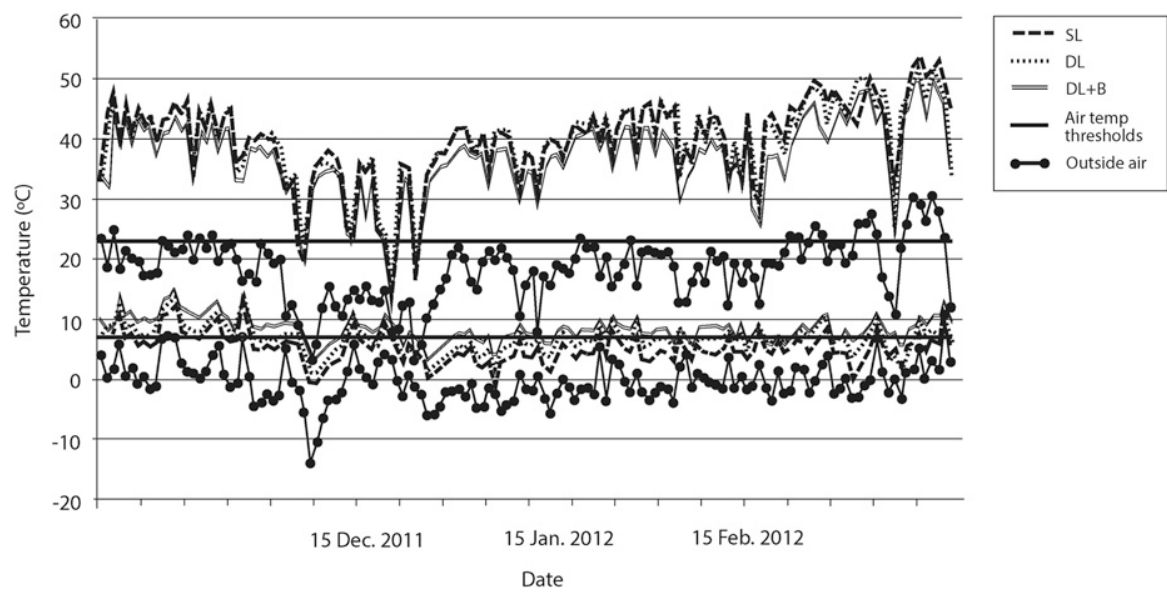

Fig. 8. Daily maximum and minimum air temperatures from under the rowcover inside three designs of high tunnels in Las Cruces, NM, during season 3 ( 2 Nov. 2011 to 19 Mar. 2012). SL = single-layer polyethylene, $\mathrm{DL}=$ double-layer polyethylene, $\mathrm{DL}+\mathrm{B}=$ double-layer polyethylene plus water barrels. Air temperature thresholds for cool-season leafy greens are referenced from Swiader and Ware (2002); $\left(1.8 \times{ }^{\circ} \mathrm{C}\right)+32={ }^{\circ} \mathrm{F}$.

and then SL estimates. Season 3 (Fig. 11) showed a significant main effect among high-tunnel designs $(P=$ $0.005)$, with lower overall estimated minimum soil temperature for SL than for either DL or DL+B $(6.5 \pm$ $0.2{ }^{\circ} \mathrm{C}$ vs. $9.1 \pm 0.2$ or $9.2 \pm 0.2{ }^{\circ} \mathrm{C}$, respectively). Overall, for season 3 , the $\mathrm{DL}+\mathrm{B}$ design was estimated to have $2.7 \pm 0.3{ }^{\circ} \mathrm{C}$ higher minimum soil temperature than the SL design.

For Las Cruces during season 1 , there was no significant difference in monthly maximum or minimum soil temperatures between the high tunnels with plastic coverings of different thicknesses. During season 2, the monthly maximum soil temperatures were not different among high-tunnel designs (Fig. 12). However, the monthly maximum temperatures for season $3[P=0.012$ (Fig. 13)] and the monthly minimum temperatures for both seasons $2[P=0.033$ (Fig. 12)] and $3[P<0.001$ (Fig. 13)] showed significant differences among hightunnel designs. During season 3 , both the DL $\left(20.6 \pm 0.2{ }^{\circ} \mathrm{C}\right)$ and $\mathrm{DL}+\mathrm{B}\left(21.3 \pm 0.2{ }^{\circ} \mathrm{C}\right)$ designs had significantly higher maximum temperatures than the SL design (19.1 \pm $0.2^{\circ} \mathrm{C}$ ). For seasons 2 and 3 , the $\mathrm{SL}$ design had significantly lower monthly minimum temperatures $\left(10.2 \pm 0.4\right.$ and $12.1 \pm 0.3{ }^{\circ} \mathrm{C}$, respectively) than both the DL (12.8 \pm 0.4 and $13.4 \pm 0.3{ }^{\circ} \mathrm{C}$ for seasons 2 and 3 , respectively) and $\mathrm{DL}+\mathrm{B}(13.8 \pm$ 0.4 and $14.1 \pm 0.3{ }^{\circ} \mathrm{C}$ for seasons 2 and 3 , respectively). For season 3 , the difference between DL+B and DL was also significant. These minimum soil temperature results are consistent with the results from seasons 1,2 , and 3 in Alcalde.

Photosynthetically active RADiATION. At Alcalde, for PAR, the design $\times$ season and sensor location $\times$ season interactions were both significant $(P=0.029$ and $<0.001$, respectively), as were the season and sensor location main effects. During season 1 , high-tunnel design SL $\left(1034 \pm 34 \mu \mathrm{mol} \cdot \mathrm{m}^{-2} \cdot \mathrm{s}^{-1}\right)$ had higher $P A R$ than either design DL $(829 \pm 34$ $\left.\mu \mathrm{mol} \cdot \mathrm{m}^{-2} \cdot \mathrm{s}^{-1}\right)$ or $\mathrm{DL}+\mathrm{B}(803 \pm 34$ $\left.\mu \mathrm{mol} \cdot \mathrm{m}^{-2} \cdot \mathrm{s}^{-1}\right)$. Although not included in the formal analysis, season 1 outside $P A R$ had a mean of 1232 $\mu \mathrm{mol} \cdot \mathrm{m}^{-2} \cdot \mathrm{s}^{-1}$ with an SD of 57 , with season 2 and 3 means slightly higher at $1460(\mathrm{sD}=6 \mathrm{l})$ and $1344(\mathrm{sD}=4 \mathrm{l})$ $\mu \mathrm{mol} \cdot \mathrm{m}^{-2} \cdot \mathrm{s}^{-1}$, respectively. For seasons 2 and 3 , differences among high-tunnel designs were not significant. During season 2, estimated high-tunnel design means were similar, ranging from $794 \mu \mathrm{mol} \cdot \mathrm{m}^{-2} \cdot \mathrm{s}^{-1}$ for SL to $800 \mu \mathrm{mol} \cdot \mathrm{m}^{-2} \cdot \mathrm{s}^{-1}$ for DL+B, whereas during season 3 the estimated means were $666 \mu \mathrm{mol} \cdot \mathrm{m}^{-2} \cdot \mathrm{s}^{-1}$ for $\mathrm{SL}, 651 \mu \mathrm{mol} \cdot \mathrm{m}^{-2} \cdot \mathrm{s}^{-1}$ for $\mathrm{DL}$, and $725 \mu \mathrm{mol} \cdot \mathrm{m}^{-2} \cdot \mathrm{s}^{-1}$ for DL+B. However, sensor locations differed for every season. In season 1 , the tops of rowcovers north and south were higher than under rowcovers north and south (Table 1). However, in seasons 2 and 3 , the top of rowcover south and the walkway consistently had higher PAR than the top of rowcover north, and the top of rowcover north had higher PAR than under rowcover north.

In Las Cruces, the season $(P=$ $0.024)$, high-tunnel design $(P=$ $0.039)$, sensor location $(P<0.001)$, and season $\times$ sensor location $(P<$ $0.001)$ effects were significant. Averaged across seasons 2 and 3 and sensor locations, the area inside the SL design received significantly more $P A R$ than inside the $\mathrm{DL}$ and $\mathrm{DL}+\mathrm{B}$ designs $\left(623 \pm 13 \mu \mathrm{mol} \cdot \mathrm{m}^{-2} \cdot \mathrm{s}^{-1}\right.$ vs. $516 \pm 13$ and $507 \pm 13 \mu \mathrm{mol} \cdot \mathrm{m}^{-2} \cdot \mathrm{s}^{-1}$, 


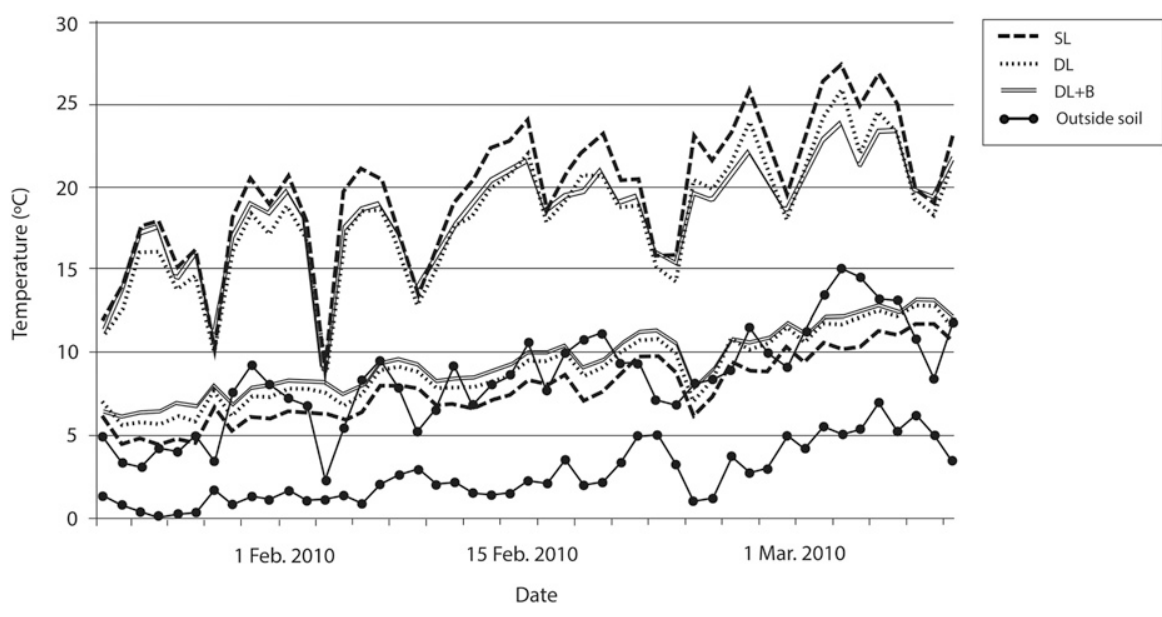

Fig. 9. Daily maximum and minimum soil temperatures from under the rowcover inside three designs of high tunnels in Alcalde, NM, during season 1 ( 22 Jan. 2010 to $9 \mathrm{Mar} .2010)$. $\mathrm{SL}=$ single-layer polyethylene, $\mathrm{DL}=$ double-layer polyethylene, $\mathrm{DL}+\mathrm{B}=$ double-layer polyethylene plus water barrels. $\left(1.8 \times{ }^{\circ} \mathrm{C}\right)+32={ }^{\circ} \mathrm{F}$.

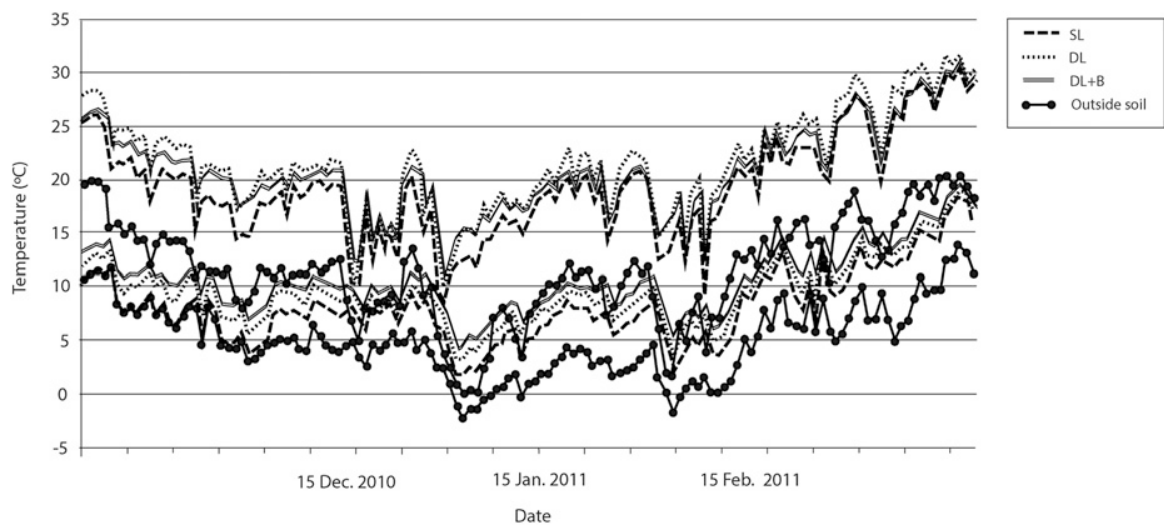

Fig. 10. Daily maximum and minimum soil temperatures from under the rowcover inside three designs of high tunnel in Alcalde, NM, during season 2 (5 Nov. 2010 to $21 \mathrm{Mar}$. 2011). $\mathrm{SL}$ = single-layer polyethylene, $\mathrm{DL}=$ double-layer polyethylene, $\mathrm{DL}+\mathrm{B}=$ double-layer polyethylene plus water barrels. $\left(1.8 \times{ }^{\circ} \mathrm{C}\right)+32={ }^{\circ} \mathrm{F}$.

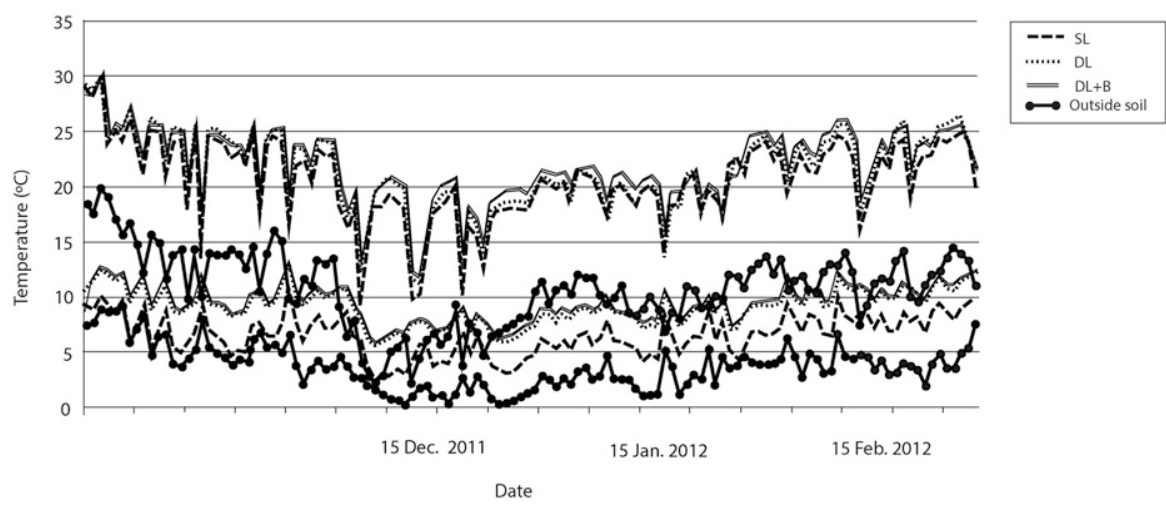

Fig. 11. Daily maximum and minimum soil temperatures from under the rowcover inside three designs of high tunnel in Alcalde, NM, during season 3 (28 Oct. 2011 to $28 \mathrm{Feb} .2012$ ). $\mathrm{SL}=$ single-layer polyethylene, $\mathrm{DL}=$ double-layer polyethylene, $\mathrm{DL}+\mathrm{B}=$ double-layer polyethylene plus water barrels. $\left(1.8 \times{ }^{\circ} \mathrm{C}\right)+32={ }^{\circ} \mathrm{F}$. respectively). Outside $P A R$ readings averaged $702 \mu \mathrm{mol} \cdot \mathrm{m}^{-2} \cdot \mathrm{s}^{-1}$ for season 2 and $1612 \mu \mathrm{mol} \cdot \mathrm{m}^{-2} \cdot \mathrm{s}^{-1}$ for season 3 . Sensor locations differed significantly for each season, with walkway and top of rowcover readings being higher than under rowcover readings. In season 3 , differences were also detected among the locations within top and under rowcover groups (Table 1).

\section{Discussion}

Outside monthly average maximum temperatures from November to February during the three seasons of the study ranged from 7.7 to $15.0{ }^{\circ} \mathrm{C}$ at Alcalde and 12.2 to $20.6^{\circ} \mathrm{C}$ at Las Cruces. Diurnal maximum and minimum air temperature swings between 20 and $25{ }^{\circ} \mathrm{C}$ were commonly observed.

High tunnels, however, can greatly modify the environment to allow for production of winter-hardy vegetables during the coldest months in New Mexico. During January, for example, monthly average maximum air temperature, averaged across high-tunnel designs, was $22{ }^{\circ} \mathrm{C}$ higher in the high tunnel under the rowcover than outside for Alcalde and up to $20^{\circ} \mathrm{C}$ higher in Las Cruces. January monthly average minimum air temperatures, averaged across high-tunnel designs, were up to $12{ }^{\circ} \mathrm{C}$ higher in high tunnels than outside in Alcalde and $10{ }^{\circ} \mathrm{C}$ higher in Las Cruces.

Some frost-sensitive crops might have sufficient protection in high tunnels and under rowcovers in Las Cruces, but not at Alcalde, because Alcalde's air temperatures fell below freezing for all high-tunnel designs during season 2 and designs SL and DL during season 3 . In Las Cruces, the $\mathrm{DL}$ and $\mathrm{DL}+\mathrm{B}$ high tunnels maintained temperatures under the rowcover above freezing during all of season 3 and all but one cold spell of $4 \mathrm{~d}$ during early February of season 2 .

The greatest effect of high-tunnel design was on minimum temperatures: soil and air at Alcalde and soil at Las Cruces. In terms of research site, design of high tunnel had the greatest effect at Alcalde, the more northern, higher-elevation, and colder site. Although heat did build up in all designs during sunny days to allow for plant growth, the double layer with or without barrels appeared to maintain more heat inside the high tunnels during nighttime, as was reflected in 


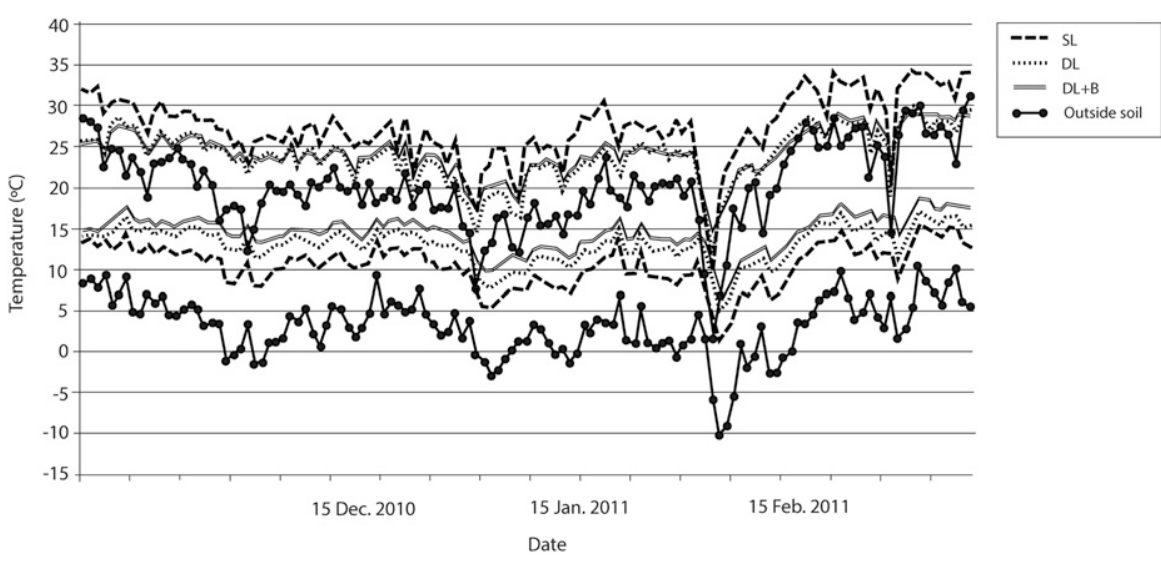

Fig. 12. Daily maximum and minimum soil temperatures from under the rowcover inside three designs of high tunnel in Las Cruces, NM, during season 2 (6 Nov. 2010 to $9 \mathrm{Mar}$. 2011). SL = single-layer polyethylene, $\mathrm{DL}=$ double-layer polyethylene, $\mathrm{DL}+\mathrm{B}=$ double-layer polyethylene plus water barrels. $\left(1.8 \times{ }^{\circ} \mathrm{C}\right)+32={ }^{\circ} \mathrm{F}$.

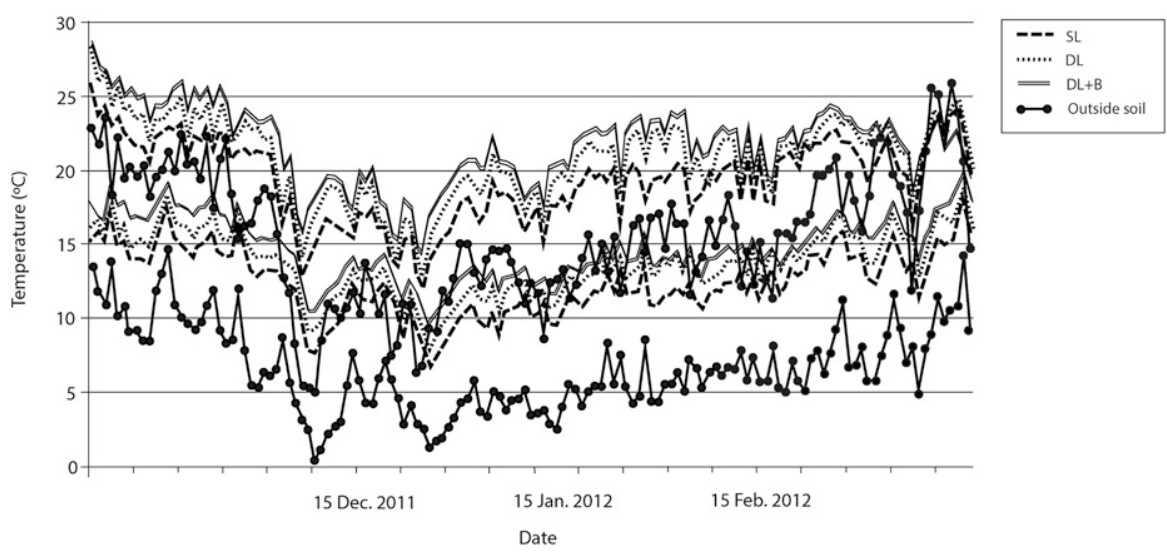

Fig. 13. Daily maximum and minimum soil temperatures from under the rowcover inside three designs of high tunnel in Las Cruces, NM, during season 3 (2 Nov. 2011 to 19 Mar. 2012). $S L$ = single-layer polyethylene, $\mathrm{DL}=$ double-layer polyethylene, $\mathrm{DL}+\mathrm{B}=$ double-layer polyethylene plus water barrels. $\left(1.8 \times{ }^{\circ} \mathrm{C}\right)+32={ }^{\circ} \mathrm{F}$.

Table 1. Photosynthetically active radiation $(P A R)$ estimates near winter solstice for various sensor locations at Alcalde, NM, and Las Cruces, NM, averaged across three high-tunnel designs.

\begin{tabular}{lcccccc}
\hline \multicolumn{3}{c}{$P A R\left(\boldsymbol{\mu m o l} \cdot \mathbf{m}^{-2} \cdot \mathbf{s}^{-1}\right)$} \\
\hline & \multicolumn{3}{c}{ Alcalde } & & \multicolumn{2}{c}{ Las Cruces } \\
\cline { 2 - 4 } \cline { 7 - 8 } Location of sensor $^{\mathrm{z}}$ & Season 1 & Season 2 & Season 3 & & Season 2 & Season 3 \\
\hline Top of rowcover N & $948 \mathrm{a}^{\mathrm{y}}$ & $735 \mathrm{~b}$ & $584 \mathrm{c}$ & & $404 \mathrm{a}$ & $791 \mathrm{~b}$ \\
Top of rowcover S & $951 \mathrm{a}$ & $944 \mathrm{a}$ & $862 \mathrm{a}$ & & $378 \mathrm{a}$ & $966 \mathrm{a}$ \\
Under rowcover N & $823 \mathrm{~b}$ & $588 \mathrm{c}$ & $329 \mathrm{~d}$ & & $283 \mathrm{~b}$ & $403 \mathrm{~d}$ \\
Under rowcover S & $828 \mathrm{~b}$ & $833 \mathrm{ab}$ & $742 \mathrm{~b}$ & & $271 \mathrm{~b}$ & $651 \mathrm{c}$ \\
Walkway & $891 \mathrm{ab}$ & $879 \mathrm{a}$ & $883 \mathrm{a}$ & & $398 \mathrm{a}$ & $948 \mathrm{a}$ \\
Outside & 1,232 & 1,460 & 1,344 & & 702 & 1,612 \\
\hline
\end{tabular}

${ }^{\mathrm{z}}$ Location of $P A R$ sensor in high tunnels: $\mathrm{N}=$ north, $\mathrm{S}=$ south. $P A R$ measurements were taken at the top of the crop canopy, $\approx 10-12$ inches $(25.4-30.5 \mathrm{~cm})$ above the soil surface.

${ }^{\mathrm{y}}$ Any two means within a column not followed by the same letter are significantly different using the F-protected least significant difference at $P \leq 0.05$.

generally higher nighttime minimum soil temperatures compared with single-layer plastic at both sites, and also higher nighttime minimum air temperatures at Alcalde. This would be an important feature of the doublelayer plastic plus rowcover to protect less cold-hardy crops.
In general, at Alcalde and Las Cruces, both maximum and minimum air temperatures in the high tunnels were buffered by the thermal mass of water in the barrels in the $\mathrm{DL}+\mathrm{B}$ high-tunnel design. The value of this extra bit of temperature moderation provided by water barrels will depend on how sensitive a given crop is to daily swings in temperature during the winter season as well as how cold-tolerant the crop is. In addition, the crop's value must be sufficient to warrant the space required by the barrels as well as the extra cost. In a study using these same high-tunnel designs (Hecher et al., 2014) to produce winter crops of lettuce and spinach, an economic analysis indicated that the SL and DL designs appeared more appropriate for both locations for spinach, and the $\mathrm{DL}+\mathrm{B}$ design might be beneficial in Alcalde, the cooler of the two research sites.

$P A R$ levels were significantly higher inside the SL design, except in Alcalde during seasons 2 and 3 . This was expected, given that this design had one layer of woven plastic and the $\mathrm{DL}$ and $\mathrm{DL}+\mathrm{B}$ designs had two layers of woven plastic. The effect may have been maintained in Las Cruces, but not Alcalde, in part because the outsides of the high tunnels in Las Cruces were rinsed with water between seasons 2 and 3 to clear away accumulated dust. With the reduction in $P A R$ in the $\mathrm{DL}$ and $\mathrm{DL}+\mathrm{B}$ designs, light intensity may have been limiting for crop growth, especially under the rowcover and around the time of the winter solstice.

In general, inside the tunnels, south sensor locations had more PAR than north, and under rowcover locations had less $P A R$ than above. These differences are expected because the south wall of structures in the northern hemisphere receives more solar radiation, and thus $P A R$, than the north side. It also follows that $P A R$ readings under the semiopaque rowcover (i.e., crop environment) were lower than within the high tunnel itself (i.e., not under rowcover).

\section{Conclusions}

In New Mexico, high tunnels have the capacity to provide a growing environment that allows production of vegetables during the coldest months of the year. We evaluated 
three passive-solar high-tunnel designs for their heat-retention capabilities at two sites in New Mexico: Las Cruces in USDA pant hardiness zone $8 \mathrm{a}$ and Alcalde in plant hardiness zone $6 a$.

We found the SL design had the lowest air and soil minimum temperatures. The DL+B design had consistently higher minimum air and soil temperatures than the SL design, resulting from the buffering effect due to the thermal mass of the water barrels. For vegetables that can tolerate temperatures that occasionally drop below freezing at night, all high-tunnel designs provided daytime temperatures that allowed for crop growth. The SL design is less expensive to build and so more likely to be profitable if growing cold-hardy winter greens (Hecher et al., 2014).

Some winter-grown frost-sensitive crops might have sufficient protection under rowcover in high tunnels using the double-layer plastic designs, DL and $\mathrm{DL}+\mathrm{B}$, at the warmer site, Las Cruces, but not at Alcalde because air temperatures there fell below freezing, except for $\mathrm{DL}+\mathrm{B}$ in one season. In Las Cruces, the $\mathrm{DL}$ and $\mathrm{DL}+\mathrm{B}$ high tunnels maintained temperatures under the rowcover above freezing except for one cold spell of 4 $\mathrm{d}$ during early February in season 2 . Environmental data from this study can assist growers when choosing high-tunnel designs for winter vegetable production.

\section{Literature cited}

Borrelli, K., R.T. Koenig, B.M. Jaeckel, and C.A. Miles. 2013. Yield of leafy greens in high tunnel winter production in the northwest United States. HortScience 48:183-188.

Both, A.J., E. Reiss, J.F. Sudal, K.E. Holmstrom, C.A. Wyenandt, W.L. Kline, and S.A. Garrison. 2007. Evaluation of a manual energy curtain for tomato production in high tunnels. Hort Technology 17:467-472.
Carey, E.E., L. Jett, W.J. Lamont, Jr., T.T. Nennich, M.D. Orzolek, and K.A. Williams. 2009. Horticultural crop production in high tunnels in the United States: A snapshot. HortTechnology 19:37-43.

Flavin Hodge, C., M. Rogers, D. Handeen, and G. Schweser. 2019. Yield of leafy greens and microclimate in deep winter greenhouse production in Minnesota. Sustainability 11:28.

Gent, M.P.N. 1992. Yield response to planting date and ventilation temperature of tomato grown in unheated high tunnels in the northeast USA. Acta Hort. 303:53-60.

Giacomelli, G.A. 2009. Engineering principles impacting high-tunnel environments. HortTechnology 19:30-33.

Hecher, E.A., C.L. Falk, J. Enfield, S.J. Guldan, and M.E. Uchanski. 2014. The economics of low-cost high tunnels for winter vegetable production in the southwestern United States. HortTechnology 24:7-15.

Heyduck, R.F., S.J. Guldan, and I. Guzman. 2019. Effect of sowing date and harvest schedule on organic spinach grown during the winter in high tunnels. HortTechnology 29:320-329.

Jimenez, D., R. Walser, and R. Torres. 2005. Hoop house construction for New Mexico: 12-ft. x 40-ft. hoop house. New Mexico State Univ. Coop. Ext. Serv. Circ. 606.

Lamont, W.J., Jr., M.D. Orzolek, E.J. Holcomb, K. Demchak, E. Burkhart, L. White, and B. Dye. 2003. Production system for horticultural crops grown in the Penn State high tunnel. HortTechnology 13:358-362.

National Oceanic and Atmospheric Administration. 2012a. Daily climate summaries, Las Cruces, New Mexico. 23 Nov. 2019. <https://www.ncdc.noaa.gov/ cdo-web/datasets/GHCND/stations/ GHCND:USC00298535/detail>.

National Oceanic and Atmospheric Administration. 2012b. Daily climate summaries, Alcalde, New Mexico. 23 Nov. 2019. <https://www.ncdc.noaa.gov/ cdo-web/datasets/GHCND/stations/ GHCND:USC00290245/detail>.
New Mexico Climate Center. 2019. Climate in New Mexico. 23 Nov. 2019. <https://weather.nmsu.edu/climate/ about $/>$.

Orzolek, M.D., W.J. Lamont, and L. White. 2004. Promising horticultural crops for production in high tunnels in the mid-Atlantic area of the United States. Acta Hort. 633:453-458.

Saglam, N. and A. Yazgan. 2000. Effects of different sowing dates and seedling grown tunnel types on earliness and yield of tomato grown under unheated high plastic tunnel. Acta Hort. 533:323-328.

Saxton, A.M. 1998. A macro for converting mean separation output to letter groupings, p. 1243-1246. In: Proc Mixed. Proc. 23rd SAS Users Group Intl., SAS Inst., Cary, NC.

Soriano, T., E.M. Suárez-Rey, M.I. Morales, M. Romero, J. Hernández, J.I. Montero, A. Antón, and N. Castilla. 2009. Solar radiation transmission in Mediterranean plastic greenhouses. Acta Hort. 807:73-78.

Swiader, J.M. and G.W. Ware. 2002. Producing vegetable crops. Interstate Publ., Danville, IL.

U.S. Department of Agriculture. 2019a. Plant hardiness zone map. 23 Nov. 2019. $<$ http://planthardiness.ars.usda.gov/ $\mathrm{PHZMWeb} />$.

U.S. Department of Agriculture. 2019b. Web soil survey. 23 Nov. 2019. <http:// websoilsurvey.nrcs.usda.gov/app/ HomePage.htm>

Wells, O.S. and J.B. Loy. 1993. Rowcovers and high tunnels enhance crop production in the northeastern United States. Hort Technology 3:92-95.

Western Regional Climate Center. 2013. Cooperative climatological data summaries, State University, New Mexico. 23 Nov. 2019. <https://wrcc.dri.edu/cgibin/cliMAIN.pl?nm8535>.

Western Regional Climate Center. 2016. Cooperative climatological data summaries, Alcalde, New Mexico. 23 Nov. 2019. <https://wrcc.dri.edu/cgi-bin/cliMAIN. pl?nm0245>. 